\title{
EXPERT EVALUATION OF CRITERIA DESCRIBING THE QUALITY OF TRAVELLING BY INTERNATIONAL PASSENGER TRAIN: TECHNOLOGICAL, ECONOMIC AND SAFETY PERSPECTIVES
}

\author{
Lijana Maskeliūnaitè ${ }^{1}$, Henrikas Sivilevičius ${ }^{2}$
}

\begin{abstract}
Department of Transport Technological Equipment, Vilnius Gediminas Technical University, Plytines g. 27, LT-10105 Vilnius, Lithuania

E-mails: ${ }^{1}$ lijana.maskeliunaite@vgtu.lt; ${ }^{2}$ henrikas.sivilevicius@vgtu.lt (correspondingauthor)
\end{abstract}

Received 19 December 2011; accepted 02 July 2012

\begin{abstract}
The goals, needs and possibilities of interested parties (administration, service staff and passengers travelling in a train) should be taken into account when organizing passenger transportation and making decisions concerning particularly this area. Improvement in passenger transportation (train travel) depends on experience, qualification and decisions made by the experts involved in this process. The paper analyses the performance of the joint-stock company Lietuvos geležinkeliai and examines criteria describing the quality of passenger transportation provided by this organization. The article presents the methods for showing the consistency of respondent and expert judgements on ranking the sets of criteria defining the quality of travelling by train. The significance of the considered criteria is based on a pair wise comparison. The employed method allows for determining the normalized weights of particular criteria with respect to other criteria of the analysed group (A, B, C, D). The article offers an algorithm for displaying the quality of train travel. The ranks assigned to the criteria by train passengers (category $\mathrm{K}$ ), service staff (category $\mathrm{P}$ ) and administrative staff (category A) are calculated establishing the differences between the ranks of criteria. The opinions of the respondents and experts belonging to categories $\mathrm{K}, \mathrm{P}$ and $\mathrm{A}$ are compared considering the significance of the adopted criteria. The paper provides the results obtained from the surveyed respondents and experts and presents the ranks given to criterion groups A, B, C, D describing the quality of train travel. Finally, the conclusions based on the performed research are presented.
\end{abstract}

Keywords: criteria for passenger transportation, railway, quality, expert evaluation, AHP method, judgement consistency, criterion weight, travel cost, train parameters, criteria for railway, travel safety, cost model.

Reference to this paper should be made as follows: Maskeliūnaite, L.; Sivilevičius, H. 2012. Expert evaluation of criteria describing the quality of travelling by international passenger train: technological, economic and safety perspectives, Technological and Economic Development of Economy 18(3): 544-566.

JEL Classification: C02, R4, L62, L92. 


\section{Introduction}

In recent years, railway transport competing in the transportation market against other means of transport has been rapidly improving. The speed and level of the comfort and safety of the trip have been steadily growing. The prospects of railway transport give hopes to transport enterprises because the majority of countries give priority to the development of passenger and freight rail transport. The stability of the railway transportation market is based on the fact that the problems of traffic jams in cities, the need for high-speed transportation and highways blocked up with heavy trucks etc. still remain unsolved. Such countries as Algeria, Argentina, Israel, India and the region of the Persian Gulf make much effort to develop rail transport. The USA possessing highly developed automobile and air transport have changed their transportation policy and are now developing high-speed railway systems (Schwieterman, Scheidt 2007). Russia is planning to renew their rolling stock and to purchase 20 thousand locomotives within the following 20 years. In 2005, great technological achievements in the central Japanese railway company helped with increasing profit by introducing superconductive magnetic systems in rail transport. The system allowing for developing a speed of 450-500 km/h was first tested in May 1998 (Nakagawa, Matsuda 2005). Now, Japanese bullet trains Shinkansen, presented to the public in 1964, use innovative technologies based on electronics (Hagiwara et al. 2007). China has also contributed to the development of high-speed railways by building a gigantic system. When testing the system on the route Beijing - Shanghai, Chinese-made locomotive CRH380A, pulling a passenger train reached a speed of $486 \mathrm{~km} / \mathrm{h}$ on 5 December 2010. The new high-speed railway route Beijing - Shanghai should be opened in 2012.

The main problem of rail transportation in a new age is to ensure the safe use of railway infrastructure and to meet the specified safety requirements (Rao, Tsai 2007). Japan's Railway Technical Research Institute is developing systems capable of detecting train position, e.g. in the tunnel or tilt of the railway car body (Sasaki 2005). In North America, simulation software and methods of statistical analysis are used for determining the capacity and operational characteristics of railway infrastructure (White 2005). Great attention is paid to the development of modern technologies promoting the use of wireless mobile equipment and networks in rail transport (Fitzmaurice 2005). Accidents with modern trains demonstrate the necessity to develop more effective systems for detecting rail defects (Scalea et al. 2005). The models are designed to identify breakdowns in the rails and to control the risk of railway accidents (Zhao et al. 2007). The rails of the railway track are tested under heavy loading ( $\mathrm{Li}$, Bilow 2008). The dynamics of the railway vehicle (Lei, Zhang 2011) of the three-dimensional interaction between the bridge and a high-speed train using a wheel-rail contact model (Dinh et al. 2009) of compressive stress induced by passing trains in permafrost subgrade along Qinghai-Tibet Railway (Zhu et al. 2011) and structural dynamics have been considered for railway transport systems (Stribersky et al. 2000). The formula for determining the dynamic coefficient that may be used as a basis for designing and evaluating bridges belonging to the urban railway system has been offered by (He et al. 2011). Works on the development and maintenance of transport system infrastructure present some risk to workers. The problem of safety in this field is considered to be of primary importance by the environmental institu- 
tions and universities of the United Kingdom. The elder (less efficient) and underqualified workers are recommended to retire or change work. The flow of workers from other countries also poses some problems due to their poor knowledge of the native language, training and getting and conveying information. Risks are based on the level of workers' qualification, knowledge and experience (Campbell et al. 2007). Roads and railroads in Italy are difficult for travelling because of a number of tunnels on the routes. Now, the total length of Italian railway routes makes $16000 \mathrm{~km}$ and includes 2000 tunnels with the total length of $1400 \mathrm{~km}$. Therefore, fire protection should be ensured on trains. Risk analysis of possible fire on the train passing through the tunnel allowed researchers (Martinelli et al. 2008) making the following conclusions: the height of the curve of the fire model presented in Italian standards is considerably reduced and is lower than that of the testing curve; when the train is full of passengers, a clear and well thought-out evacuation plan should be prepared. The rescue of passengers largely depends on their conscious behaviour and quick reaction time. Therefore, fire detection and alarm systems in passenger cars play a critical role. Gašparík and Zitrický (2010) propose a new approach to evaluating the capacity consumption of a track line (occupation time) based on the graphic approach.

Now, large networks of high-speed railways operate in Europe and Japan. However, in Japan, they compete with air transport while in Europe they supplement each other (Clever, Hansen 2008). The cooperation of trains in a multimodal international railway transport system is considered along with the plan of extending an intermodal network to embrace eleven countries from Scandinavia to Greece via Bulgaria, the Czech Republic, Hungary, Poland, Romania and Slovakia (Kuo et al. 2008). The development of European Rail Traffic Management Systems (ERTMS) requires appropriate methods of modelling (simulation) (Jabri et al. 2010). To attract more passengers, transport services should be improved: in addition to high-quality rolling stock, highly qualified staff should be trained. The problems of theoretical knowledge and practical skills of employees have been in the focus of researchers of various fields in the last decades. In light of rail transport, training programmes of managing staff (train crew) are developed and practically used (Morgan et al. 2007). Maintenance costs of freight locomotives (of particular series) are analysed and assessed thus recommending the ways of reducing them (Bureika 2011). Research into the fault rate of railway trains is carried out (Gelumbickas, Vaičiūnas 2011) and physical characteristics of metal used for the wheelset tyre are modelled (Bazaras, Somov 2011). Mathematical models of making-up trains allowing for optimizing them on each route and a type of traction are developed (Dailydka 2010; Ramunas et al. 2011) determining criteria for evaluating passenger transportation by rail and their significance (Maskeliūnaitè et al. 2009; Sivilevičius, Maskeliūnaitė 2010; Maskeliunaite, Sivilevicius 2011; Si et al. 2009; Preston et al. 2009).

The present paper is aimed at ensuring (employing expert methods) the consistency of judgements made by the respondents (passengers), experts (service staff of the train 'Vilnius-Moscow' and administrative staff of the Passenger Transportation Directorate of the joint-stock company Lietuvos geležinkeliai) considering the weight (significance) of criterion groups A, B, C and D describing the quality of passenger transportation. The obtained data are required for creating an additional model. 


\section{Description activities undertaken by the joint-stock company Lietuvos geležinkeliai and criteria explaining the quality of passenger transportation}

Passenger transportation is a specific area of social and economic importance associated with the main problem of the state - the provision of the freedom of travel (movement) (Belov et al. 2001).

Social expenses on railway transport consist of the maintenance costs of railways (infrastructure), the costs of renewing and maintaining rolling stock (repairing old and purchasing new locomotives) (Fig. 1) and expenses on the passengers of trips. The costs of passenger transportation services may differ depending on their quality.

An increase in the quality of rolling stock and railways decreases the costs of travelling. Due to an increase in speed, travel time and a chance to be involved in a railway traffic accident (avoid medical and insurance costs) reduces.

The costs of railway maintenance and development are related to its construction, repair and maintenance. Expenses on stock renewal, purchasing, repair and maintenance, including the costs of fuel, electric power, spare parts, oil, workers' payment, etc. make the major part of these costs.

The expenses of rail transport users are related to fare losses experienced due to delays to trips, traffic accidents, environment pollution and a lack of comfort during the trip.

By increasing the costs of railway staff to some extent, the total expenses of passengers and society can be decreased. When the variation curves of railway staff and passengers cross each other, social expenses are the lowest, i.e. optimal quality level is achieved. A lack of investment in infrastructure and rolling stock results in a low quality of a railway travel or makes this transport facility unattractive to passengers.

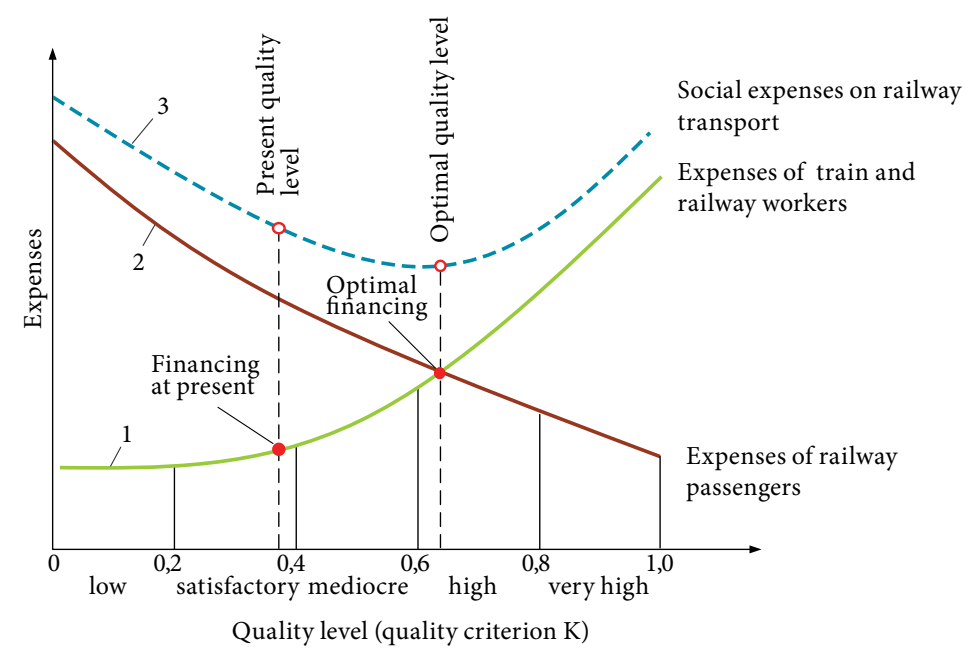

Fig. 1. The model for the dependence of the costs of passenger rail transport on the level of trip quality: 1) expenses on train and railway staff; 2) expenses of railway passengers;

3) (total) social expenses 
To attract more passengers, the quality of transportation should be improved: in addition to high-quality rolling stock, highly qualified staff should be trained. Therefore, for several decades, the problems of theoretical and practical knowledge of employees have been in the focus of researchers from various countries. The suggested model of a potential evaluation of knowledge has been adapted to the transport sector. Taking into account a specific character of criteria describing it, the model is based on education, professional experience, position, dutifulness, the scope of decision making and responsibility as well as on self-dependence at work and work culture. Some researchers also emphasize the use of technologies and the level of difficulty at work, motivation and employee's contribution to achievements in the goals of the organization (Morkvenas et al. 2008). An important point is identifying the problems of passenger transportation using rail transport in a particular country, i.e. a decrease in passenger flows, the growth of transportation cost and insufficient financing of unprofitable means of transportation.

At the moment, the joint-stock company Lietuvos geležinkeliai is facing positive changes. The company has invested 3.6 billion Lt during the last 10 years and now has a modern park of freight locomotives. Modern signalling, telecommunication and locomotive control systems are introduced into operation on major routes and at railway stations. Many railway buildings and passenger waiting rooms have been renovated and new energy-efficient passenger locomotives have been purchased. In May 2010, work on the project Rail Baltica started. The introduced project is a railway line connecting Warsaw, Kaunas, Riga, Tallinn and Helsinki. The route will allow the further development of railway service, i.e. freight and passenger transportation between the Baltic States and European countries. The Republic of Lithuania considers Rail Baltica to be an economic project of national importance.

In 2010, the trains of the company Lietuvos geležinkeliai were running on 52 local and 2 international routes. 189 trains were operating on local routes and 4 trains - on international routes. Eighteen trains from foreign railway companies arrived at Lithuania or went in transit through Lithuanian territory.

The dynamics of passenger transportation in 2007-2010 is shown in Fig. 2. In 2010, 4.4 million passengers, i.e. nearly the same number as in 2009 , were carried by trains, including

- 3.5 million passengers carried by local trains;

- 0.9 million passengers carried by international trains.

Compared to data on 2009, income from passenger transportation has grown by $15.7 \%$ (Lietuvos geležinkeliai. Annual report 2010).

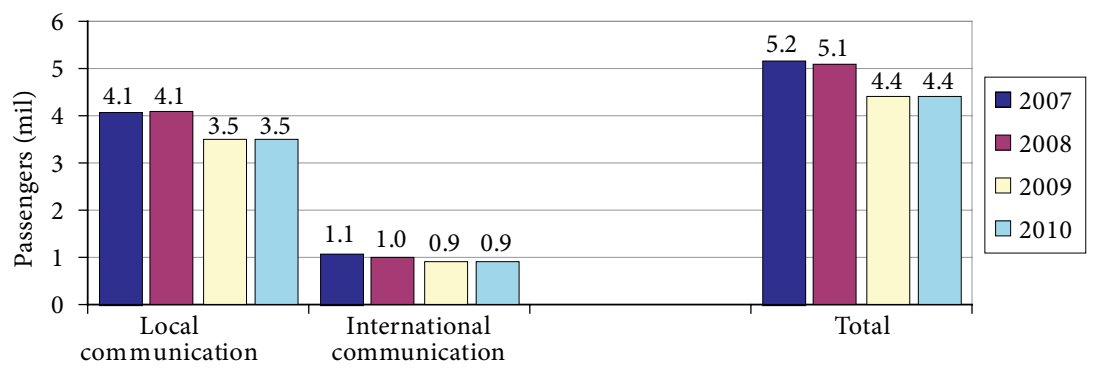

Fig. 2. The dynamics of passenger flows in 2007-2010 (mil)

(Lietuvos geležinkeliai. Annual report 2010) 
As shown in Table 1, the flows of passengers hardly changed (Table 1). The company carried about 4.4 million passengers in 2010 and the same number is found in 2009.

Table 1. Passenger flows in 2006-2010 (Lietuvos geležinkeliai. Annual report 2010)

\begin{tabular}{lcccc}
\hline Year & 2007 & 2008 & 2009 & 2010 \\
\hline Payload quantity, mil passengers & 5.2 & 5.1 & 4.4 & 4.4 \\
\hline Revenue passenger kilometres, mil & 408.7 & 397.5 & 356.9 & 373.1 \\
\hline Average distance per passenger, km & 78.8 & 78.5 & 81.6 & 85.5 \\
\hline Average number of trips per inhabitant of the country & 2 & 2 & 1 & 1 \\
\hline
\end{tabular}

\section{Methods for evaluating the consistency of judgements made by respondents and experts to determine the significance of criterion groups describing the quality of railway trips}

The quality of passenger transportation is described by a number of criteria the significance (importance) of which differs to various extent and is expressed in different measurement units or that of dimensionless criteria may be determined, based on their comparison performed by experts. The methods of expert evaluation allow for more effective organization of analytical work done by experts and are the problem of a quantitative evaluation of opinions and processing of the results obtained. The generalized estimate of a group of experts is taken as a decision (problem situation). If the decision was made by experts, the consistency of expert judgements would be evaluated. This is particularly important, because multi-criteria evaluation methods are used (Zavadskas 1987; Podvezko 2005; Saaty 1980; Maskeliūnaitè et al. 2009; Brauers et al. 2008; Sivilevičius et al. 2008). The consistency of expert judgements is described by the concordance coefficient.

The concept of the concordance coefficient of Kendall (1970) is based on the sum of ranks of each criterion $R_{j}$ taking into account judgements made by all experts:

$$
R_{j}=\sum_{i=1}^{n} R_{i j}(j=1,2, \ldots, m) .
$$

To be more precise, it is related to the deviation of value $R_{j}$ from the sum of squares $S$ (analogue of variance) of the total mean $\bar{R}$ :

$$
S=\sum_{j=1}^{m}\left(R_{j}-\bar{R}\right)^{2} .
$$

The average rank $\bar{R}$ of any criterion is obtained by dividing its sum of ranks by the number of the criterion:

$$
\bar{R}=\frac{\sum_{j=1}^{m} R_{j}}{m} \text { or } \bar{R}=\frac{\sum_{i=1}^{n} \sum_{j=1}^{m} R_{i j}}{m}=\frac{n(m+1)}{2},
$$

where $R_{i j}$ is the rank assigned by the $i$-th expert (respondent) to the $j$-th criterion; $n$ is the number of experts $(i=1,2, \ldots, n) ; m$ is the number of the criterion $(j=1,2, \ldots, m)$. 
The average rank $\bar{R}_{j}$ of each criterion is obtained by dividing the sum of the given ranks by the number of experts:

$$
\bar{R}_{j}=\frac{\sum_{i=1}^{n} R_{i j}}{n}(j=1,2, \ldots, m),
$$

where $R_{i j}$ is the rank given by expert $i$ to criterion $j$; $n$ - the number of experts.

If $S$ is a real sum of squares obtained by formula (2), the concordance coefficient, in the absence of tied ranks, is defined by the relationship between the obtained $S$ and respective maximum $S_{\max }$ (Kendall 1970):

$$
W=\frac{12 S}{n^{2} m\left(m^{2}-1\right)}=\frac{12 S}{n^{2}\left(m^{3}-m\right)} .
$$

The sum of squares $S$ of the deviations of each criterion's ranks $R_{i j}$ from the average rank can be calculated applying the formula:

$$
S=\sum_{j=1}^{m}\left[\sum_{i=1}^{n} R_{i j}-\frac{1}{2} n(m+1)\right]^{2},
$$

where $m$ is the number of criteria $(j=1,2, \ldots, m) ; n$ is the number of experts (respondents) $(i=1,2, \ldots, n)$.

Random value $S$ is calculated by adding all values assigned to all considered objects.

The concordance coefficient may be used practically if its limit value (when expert estimates are consistent) is determined. M. Kendall has proved that if the number of objects (criteria) is $m>7$, the significance of the concordance coefficient may be determined using $\chi^{2}$ (chi-square) Pearson criterion.

The random value

$$
\chi^{2}=n(m-1) W=\frac{12 S}{n m(m+1)}
$$

is distributed according to $\chi^{2}$ distribution with $v=m-1$ degree of freedom. According to the specified level of significance $\alpha$ (under real conditions, $\alpha$ is chosen to be equal to 0,05 or even 0,01$)$, critical value $\chi_{k r}^{2}=\chi_{v ; \alpha}^{2}$ is taken from the table of $\chi^{2}$ distribution with $v=m-1$ degree of freedom. If $\chi^{2}$ calculated by formula (7) is larger than $\chi_{k r}^{2}$, it means that expert (respondent) estimates are consistent.

When the number of compared criteria $m$ ranges from 3 to 7 , distribution $\chi^{2}$ should be used sparingly because the critical value of $\chi_{k r}^{2}$ may be higher than the calculated value, though the consistency of expert estimates is still considered to be sufficient. In this case, the probability tables of the concordance coefficient or the tables of critical values $S$ (with $3 \leq m \geq 7$ )) should be used (Podvezko 2005).

The lowest value of concordance coefficient $W_{\text {min }}$ does not allow us stating that the estimates of all $n$ experts (respondents) of the quality of the investigated object based on $m$ 
criteria and having the specified (required) significance $\alpha$ and the degree of freedom $v=m-1$ are consistent and can be calculated using the formula suggested by (Sivilevičius 2011b):

$$
W_{\min }=\frac{\chi_{v, \alpha}^{2}}{n(m-1)},
$$

where $\chi_{v, \alpha}^{2}$ is the critical value of the Pearson's statistic, found with reference to the table taking the degree of freedom and significance $\alpha\left(\chi_{v, \alpha}^{2}=\chi_{k r}^{2}\right)$.

In practice, it is easier to use the significances with the largest (the best) values (Zavadskas 1987).

When the quality of an object is determined by an additive mathematical model used for calculating a complex (integrated) quality criterion (allowing quality to be defined by a single number and compared to the quality of other objects), significance indicators $Z_{j}$ rather than average ranks $\bar{R}_{j}$ should be used, which does not indicate the significance level of one or another rank.

The significance of criteria describing the quality of the object evaluated by experts can be determined normalizing them (i.e. making their sum equal to one) and calculating the significance indicator $Z_{j}$ of each criterion from the formula given in (Sivilevičius 2011b):

$$
Z_{j}=\frac{(m+1)-\bar{R}_{j}}{\sum_{j=1}^{m} \bar{R}_{j}},
$$

where $m$ is the number of criteria describing the quality (characteristics) of the considered object; $\bar{R}_{j}$ is the average rank of the $j$-th criterion calculated by formula (4).

\section{Criteria describing the quality of a railway trip and determining their significance by applying the method of comparative analysis}

Criteria describing the quality of passenger transportation by railway (railway trip) were determined and grouped (Table 2). The conducted analysis was based on the application of the AHP method. Criteria describing the quality of the railway trip were collected and appropriate questionnaires on a survey were prepared and later distributed among the respondents (passengers) and experts (service staff and representatives of the Passenger Transportation Directorate of the joint-stock company Lietuvos geležinkeliai). The diagram of criteria for establishing the quality of railway trips is divided into groups A, B, C and D (structure of the questionnaire) and given in Table 2 . The survey was conducted within the period from 3 September 2007 to 16 January 2008. The questionnaire was translated into English and Russian languages. Thirty two questionnaires were distributed among the passengers representing eighteen citizens of Lithuania, nine of Russia, one of the USA, one of Spain, one of Italy, one of Germany and one of Great Britain. However, only 10 questionnaires were completed by the passengers ( 3 from Lithuania, 4 from Russia, 1 from the USA, 1 from Germany and 1 from Italy) and actually used in the survey because the remaining 22 questionnaires were found 
to be inconsistent and, therefore, rejected. Moreover, 17 questionnaires were given to experts (i.e. service staff) and only 11 of those were used in the survey. Four questionnaires were handed over to the managers of the department of passenger transportation of the joint-stock company Lietuvos geležinkeliai and only three of those were applied in the survey. Meanwhile, one completed questionnaire was rejected for the reason described above.

The matrix comparing evaluation criteria $\left(a_{j i}=1 / a_{i j}\right)$ is as follows (Saaty 1980; Sivilevičius 2011a; Turskis, Zavadskas 2010; Vilčeková et al. 2011):

$$
A=\left(a_{i j}\right)=\left[\begin{array}{cccc}
1 & \frac{w_{1}}{w_{2}} & \cdots & \frac{w_{1}}{w_{m}} \\
\frac{w_{2}}{w_{1}} & 1 & \cdots & \frac{w_{2}}{w_{m}} \\
\vdots & \vdots & \ddots & \vdots \\
\frac{w_{m}}{w_{1}} & \frac{w_{m}}{w_{2}} & \cdots & 1
\end{array}\right],
$$

Table 2. Criterion groups A, B, C and D describing the quality of the railway trip

\begin{tabular}{|c|c|c|c|}
\hline $\begin{array}{l}\text { A. Criteria for train } \\
\text { elements } \\
\text { and technical state } \\
\text { of rails (railway track) }\end{array}$ & $\begin{array}{l}\text { B. Criteria for railway trip } \\
\text { planning and technology }\end{array}$ & $\begin{array}{l}\text { C. Criteria for the price } \\
\text { of a trip ticket }\end{array}$ & $\begin{array}{l}\text { D. Criteria for a safe } \\
\text { railway trip }\end{array}$ \\
\hline $\begin{array}{l}\text { 1. Roughness of a railway } \\
\text { track }\end{array}$ & $\begin{array}{l}\text { 1. Departure and arrival of trains } \\
\text { at the scheduled time }\end{array}$ & 1. Ticket price & $\begin{array}{l}\text { 1. Availability } \\
\text { of equipment } \\
\text { for fire safety }\end{array}$ \\
\hline $\begin{array}{l}\text { 2. Speed of train travel } \\
\text { (trip duration) }\end{array}$ & $\begin{array}{l}\text { 2. Delivery of meals included } \\
\text { into the ticket price }\end{array}$ & $\begin{array}{l}\text { 2. Price of meals served } \\
\text { in the dining-room }\end{array}$ & $\begin{array}{l}\text { 2. Availability of first } \\
\text { medical aid }\end{array}$ \\
\hline $\begin{array}{l}\text { 3. State of coach exterior } \\
\text { (cleanness, deformation, } \\
\text { damage) }\end{array}$ & $\begin{array}{l}\text { 3. Delivery of bedclothes and } \\
\text { their condition; making up } \\
\text { the bed and its condition }\end{array}$ & $\begin{array}{l}\text { 3. Price of newspapers } \\
\text { and magazines }\end{array}$ & $\begin{array}{l}\text { 3. Possibility of calling } \\
\text { an ambulance }\end{array}$ \\
\hline $\begin{array}{l}\text { 4. Noise reduction } \\
\text { measures (measures } \\
\text { of noise insulation) }\end{array}$ & $\begin{array}{l}\text { 4. Possibility of ordering meals } \\
\text { and beverages from the dining } \\
\text { to the compartment } \\
\text { (by car attendant) }\end{array}$ & $\begin{array}{l}\text { 4. Price of health } \\
\text { insurance card } \\
\text { valid abroad }\end{array}$ & $\begin{array}{l}\text { 4. Operational state } \\
\text { of axle-box overheat } \\
\text { and fire alarm } \\
\text { system }\end{array}$ \\
\hline 5. Passenger coach interior & $\begin{array}{l}\text { 5. Onboard distribution } \\
\text { of popular press }\end{array}$ & 5. Price of the visa & $\begin{array}{l}\text { 5. Availability of } \\
\text { emergency exits }\end{array}$ \\
\hline $\begin{array}{l}\text { 6. Operation of ventilation, } \\
\text { air conditioning, cooling } \\
\text { and lighting systems in } \\
\text { terms of their timely } \\
\text { switch on/off }\end{array}$ & $\begin{array}{l}\text { 6. Possibility of access } \\
\text { to the Internet }\end{array}$ & $\begin{array}{l}\text { 6. Delivery of meals } \\
\text { (included into ticket } \\
\text { price) to passengers } \\
\text { going in the first-class } \\
\text { double compartment }\end{array}$ & $\begin{array}{l}\text { 6. Condition of } \\
\text { handrails, stairs, } \\
\text { tambours, doors } \\
\text { nd locks }\end{array}$ \\
\hline
\end{tabular}

Criteria for the quality of the railway trip 
End of Table 2

\begin{tabular}{|c|c|c|c|}
\hline \multicolumn{4}{|c|}{ Criteria for the quality of the railway trip } \\
\hline $\begin{array}{l}\text { 7. Temperature required } \\
\text { inside a passenger car }\end{array}$ & $\begin{array}{l}\text { 7. Possibility of buying a ticket } \\
\text { on the train (from the train } \\
\text { manager) }\end{array}$ & - & $\begin{array}{l}\text { 7. Operational state } \\
\text { of a hand brake }\end{array}$ \\
\hline $\begin{array}{l}\text { 8. Type (simple or } \\
\text { vacuum) and condition } \\
\text { of sanitary units } \\
\text { (lavatories) }\end{array}$ & $\begin{array}{l}\text { 8. Possibility of reserving } \\
\text { a seat in the dining }\end{array}$ & - & $\begin{array}{l}\text { 8. Possibility of calling } \\
\text { the police (militia) }\end{array}$ \\
\hline $\begin{array}{l}\text { 9. Construction of } \\
\text { plank-beds (safety } \\
\text { belts of upper level } \\
\text { plank-beds), special } \\
\text { facilities for people } \\
\text { with disabilities }\end{array}$ & 9. Possibility of calling a taxi & - & - \\
\hline $\begin{array}{l}\text { 10. Availability of a } \\
\text { regularly operating } \\
\text { shower }\end{array}$ & $\begin{array}{l}\text { 10. Possibility of settling for } \\
\text { onboard services using } \\
\text { payment cards }\end{array}$ & - & - \\
\hline $\begin{array}{l}\text { 11. Special compartments } \\
\text { for transporting } \\
\text { bicycles }\end{array}$ & 11. Onboard sales of souvenirs & - & - \\
\hline 12. Smoking places & $\begin{array}{l}\text { 12. Music broadcast and } \\
\text { information in conformity } \\
\text { with passenger requests }\end{array}$ & - & - \\
\hline $\begin{array}{l}\text { 13. Radio broadcasting } \\
\text { unit and its centralized } \\
\text { operation (switching } \\
\text { on/off) }\end{array}$ & $\begin{array}{l}\text { 13. Safekeeping of passenger } \\
\text { luggage and personal items }\end{array}$ & - & - \\
\hline $\begin{array}{l}\text { 14. Dining-car } \\
\text { (buffet-car) }\end{array}$ & $\begin{array}{l}\text { 14. Possibility of acquiring a } \\
\text { health insurance card valid } \\
\text { abroad }\end{array}$ & - & - \\
\hline $\begin{array}{l}\text { 15. Possibility of } \\
\text { calling an attendant } \\
\text { to a passenger } \\
\text { compartment in } \\
\text { emergency cases }\end{array}$ & $\begin{array}{l}\text { 15. Possibility of obtaining a visa } \\
\text { at the cross border station }\end{array}$ & - & - \\
\hline $\begin{array}{l}\text { 16. Possibility of using } \\
\text { tools (hairdryer, iron, } \\
\text { etc.) }\end{array}$ & $\begin{array}{l}\text { 16. Exterior appearance } \\
\text { off service staff (uniform, } \\
\text { footwear, hairstyle, } \\
\text { identification card) }\end{array}$ & - & - \\
\hline- & $\begin{array}{l}\text { 17. Communication culture of } \\
\text { service staff (with passengers } \\
\text { and colleagues) }\end{array}$ & - & - \\
\hline- & $\begin{array}{l}\text { 18. Foreign language skills } \\
\text { of service staff }\end{array}$ & - & - \\
\hline- & $\begin{array}{l}\text { 19. Competence, impersonality } \\
\text { and communication culture } \\
\text { of customs and cross border } \\
\text { station officers while dealing } \\
\text { with passengers }\end{array}$ & - & - \\
\hline
\end{tabular}


All RTQ criteria were divided into criterion groups A, B, C and D (Table 2) using AHP (Analytic Hierarchy Process) technique. The respondents belonging to three categories, i.e. train passengers ( category $\mathrm{K}$ ), service staff (category $\mathrm{P}$ ) and administrative staff (category $\mathrm{A}$ ) as well as experts filled in the questionnaires. The respondents and experts (Fig. 3) had to compare the criteria in each group thus determining the weight (significances) of the criteria at a particular hierarchical level with respect to a higher hierarchical level or to non - structured criteria. The largest eigenvalue $\lambda_{\max }$, C.I. (consistency index) and C.R. (consistency ratio) were calculated for each questionnaire. The questionnaires with inconsistent evaluation data were rejected. The estimates of RTQ criteria found in the properly completed questionnaires were assigned particular ranks (Table 3) and checked if there were any matching estimates provided by the same respondents and experts, i. e. if they were consistent (Table 4).

\section{Comparative analysis of the estimates provided by the respondents and experts}

The significant estimates of the $j$-th criterion in group A elicited from the respondents and experts of all three categories (K, P, A) are expressed by weight coefficient $\bar{Q}_{A j}$ calculated by the formula:

$$
\bar{Q}_{A j}=\frac{\sum_{e=1}^{3} Q_{A j e}}{3}=\frac{Q_{A j K}+Q_{A j P}+Q_{A j A}}{3},
$$

where $Q_{A j e}$ is weight coefficient $(j=1,2, \ldots, m)$ assigned to the $j$-th criterion of criterion group A (in the questionnaires) by the experts (representing respondent category e); $Q_{A j K}$ is weight coefficient assigned to the $j$-th criterion of criterion group A by the passengers; $Q_{A j P}$ is weight coefficient assigned to the $j$-th criterion of criterion group A by service staff; $Q_{A j A}$ is weight coefficient assigned by administrative staff to the $j$-th criterion of criterion group A.

Mean weight coefficients $\bar{Q}_{B j}, \bar{Q}_{C j}, \bar{Q}_{D j}$ of the criteria in other groups (B, C, D) were calculated using similar formulas (Table 3).

Thus, the profound analysis of the significance estimates of quality criteria for passenger transportation (railway trips) has shown that criteria A7, A2 and A6, B1, B15 and B13, C1, C5 and C4, D4, D1 and D7 are the most significant to respondents and experts (Tables 2 and 3) (Maskeliūnaitè et al. 2009; Sivilevičius, Maskeliūnaitė 2010).

Given the ranks assigned by the experts and respondents of a particular category to RTQ criterion (Table 3), the consistency of their estimates may be determined based on the sum of differences in ranks. The smaller is the sum of the module of differences in the ranks assigned to the criteria by two categories of the respondents and experts or experts and experts, the more uniform are the estimates. The average differences between the ranks are calculated by the formula

$$
\bar{R}_{1-2}=\frac{\sum_{j=1}^{m}\left|R_{1-2}\right|_{j}}{m},
$$

where $\left|R_{1-2}\right|_{j}$ is the modulus of differences (absolute value) in the ranks assigned to criterion groups ( $\mathrm{A}, \mathrm{B}, \mathrm{C}$ or $\mathrm{D}$ ) or to the $j$-th criterion by the criteria or by the experts and experts; 
$m$ is the number of the criteria in a group; indices $\mathrm{R} 1$ and $\mathrm{R} 2$ denote the respondents of the $1^{\text {st }}$ and $2^{\text {nd }}$ categories and experts the criterion ranks of whose are compared. When the ranks given to all criteria of the group by the respondents and experts match each other, then, $\bar{R}_{1-2}=0$, and the estimates are the same. When value $\bar{R}_{1-2}$ is growing, differences in the estimates are also increasing. The calculated $\bar{R}_{1-2}$ values (Table 4) show that, in criterion group $\mathrm{A}$, the estimates of all criteria elicited from the passengers and administrative staff are more consistent (close to each other) $\left(\bar{R}_{K-A}=2.31\right)$. Data on criterion group $B$ show that the estimates elicited from the service and administrative staff of the train are more consistent $\left(\bar{R}_{P-A}=1.89\right)$. Information on criterion group $C$ indicate that estimates for the significance of criteria elicited from passengers and administrative staff are absolutely the same $\left(\bar{R}_{K-A}=0\right)$. Data on criterion group D discloses that more consistent estimates for the significance of criteria were elicited from service and administrative staff $\left(\bar{R}_{P-A}=1.25\right)$.

Table 3. The mean values of weight coefficients and average ranks assigned to RTQ criteria by the respondents and experts

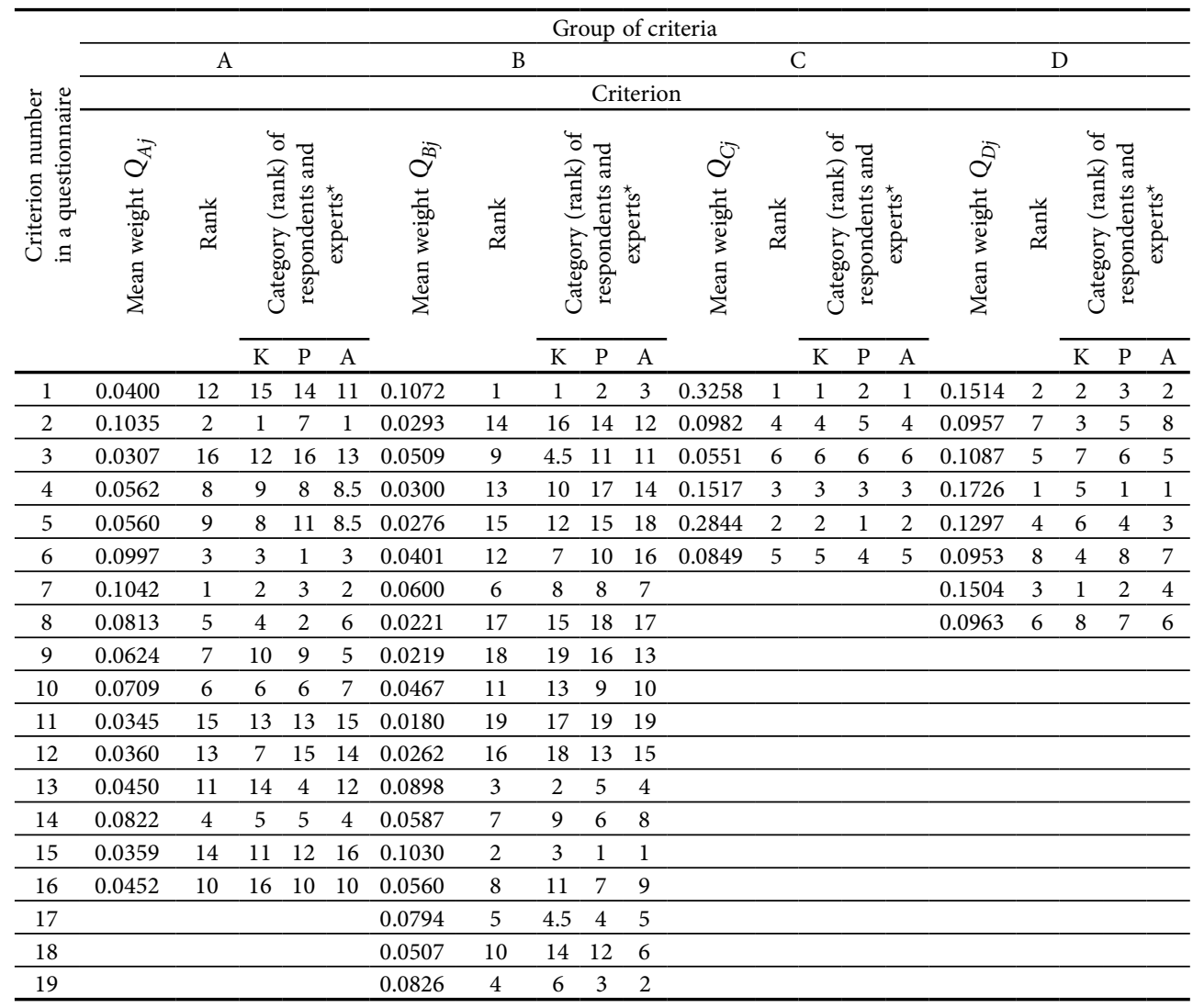

${ }^{\star}$ The categories of respondents and experts: $\mathrm{K}$ - passengers, $\mathrm{P}$ - service staff, $\mathrm{A}$ - administration staff 


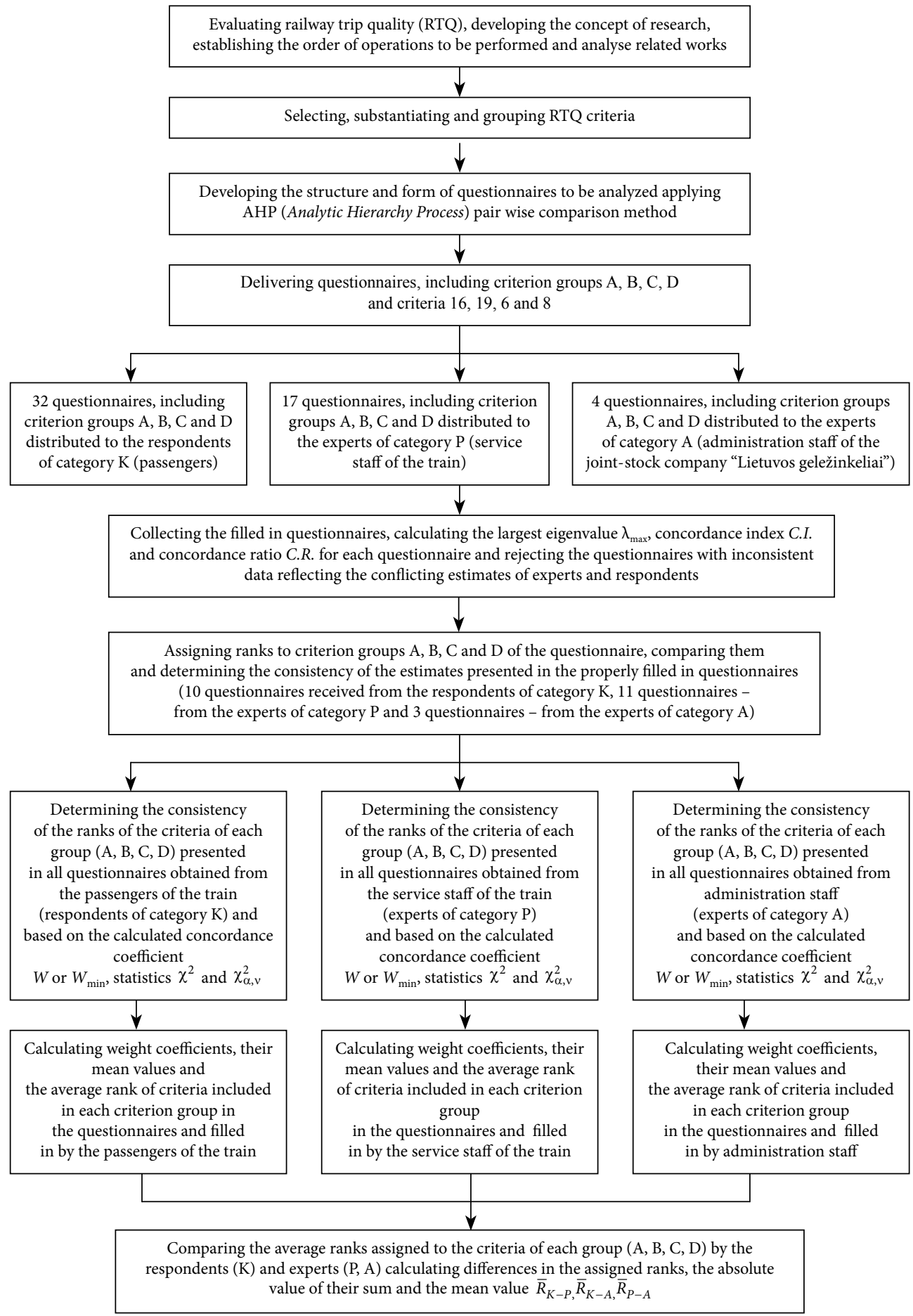

Fig. 3. The algorithm for evaluating the quality of a railway trip 
Table 4. Differences in the ranks assigned to criteria describing the quality of a railway trip

\begin{tabular}{|c|c|c|c|c|c|c|c|c|c|c|c|c|}
\hline \multirow{4}{*}{ 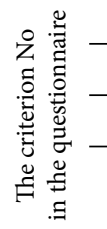 } & \multicolumn{12}{|c|}{ Group of criteria } \\
\hline & \multicolumn{3}{|c|}{ A } & \multicolumn{3}{|c|}{ B } & \multicolumn{3}{|c|}{$\mathrm{C}$} & \multicolumn{3}{|c|}{$\mathrm{D}$} \\
\hline & \multicolumn{12}{|c|}{ Pairs of particular category respondents and experts compared in the analysis } \\
\hline & $R_{K-P}$ & $R_{K-A}$ & $R_{P-A}$ & $R_{K-P}$ & $R_{K-A}$ & $R_{P-A}$ & $R_{K-P}$ & $R_{K-A}$ & $R_{P-A}$ & $R_{K-P}$ & $R_{K-A}$ & $R_{P-A}$ \\
\hline 1 & 1 & 4 & 3 & -1 & -2 & -1 & -1 & 0 & 1 & -1 & 0 & 1 \\
\hline 2 & -6 & 0 & 6 & 4 & 4 & 2 & -1 & 0 & 1 & -2 & -5 & -3 \\
\hline 3 & -4 & -1 & 3 & -6.5 & -6.5 & 0 & 0 & 0 & 0 & 1 & 2 & 1 \\
\hline 4 & 1 & 0.5 & -0.5 & -7 & -4 & 3 & 0 & 0 & 0 & 4 & 4 & 0 \\
\hline 5 & -3 & -0.5 & 2.5 & -3 & -6 & -3 & 1 & 0 & -1 & 2 & 3 & 1 \\
\hline 6 & 2 & 0 & -2 & -3 & -9 & -6 & 1 & 0 & -1 & -4 & -3 & 1 \\
\hline 7 & -1 & 0 & 1 & 0 & 1 & 1 & & & & -1 & -3 & -2 \\
\hline 8 & 2 & -2 & -4 & -3 & -2 & 1 & & & & 1 & 2 & 1 \\
\hline 9 & 1 & 5 & 4 & 3 & 6 & 3 & & & & & & \\
\hline 10 & 0 & -1 & -1 & 4 & 3 & -1 & & & & & & \\
\hline 11 & 0 & 2 & -2 & -2 & -2 & 0 & & & & & & \\
\hline 12 & -8 & -7 & 1 & 5 & 3 & -2 & & & & & & \\
\hline 13 & 10 & 2 & -8 & -3 & -2 & 1 & & & & & & \\
\hline 14 & 0 & 1 & 1 & 3 & 1 & -2 & & & & & & \\
\hline 15 & -1 & -5 & -4 & 2 & 2 & 0 & & & & & & \\
\hline 16 & 6 & 6 & 0 & 4 & 2 & -2 & & & & & & \\
\hline 17 & & & & 0.5 & -0.5 & -1 & & & & & & \\
\hline 18 & & & & 2 & 8 & 6 & & & & & & \\
\hline 19 & & & & 3 & 4 & 1 & & & & & & \\
\hline$\sum_{j=1}^{m}\left|R_{1-2}\right|_{j}$ & 46 & 37 & 43 & 59 & 68 & 36 & 4 & 0 & 4 & 15 & 22 & 10 \\
\hline $\bar{R}_{1-2}$ & 2.87 & 2.31 & 2.69 & 3.11 & 3.58 & 1.89 & 0.67 & 0 & 0.67 & 1.88 & 2.75 & 1.25 \\
\hline
\end{tabular}

\section{Results of the survey into respondent and expert opinions on the significance of criterion groups describing the quality of a railway trip}

When grouping criteria describing passenger transportation by railway (railway trip) and establishing their weight (significance), the preference order or ranks of criterion groups $\mathrm{A}, \mathrm{B}, \mathrm{C}$ and $\mathrm{D}$ were determined.

Twenty one passengers of the train 'Vilnius-Moscow' and 29 experts (including 20 service staff members of the train and 9 members of the administrative staff of the company Lietuvos geležinkeliai) competent in describing the structure and constituent parts of the train, the technical state of the railway, the management and technology of a railway trip, provisions for trip safety and requirements for the quality of transportation were given questionnaires (Table 5) and asked to assign ranks according to their importance and considering criterion groups A, B, C and D (Table 2) describing the quality of the railway trip. Based on the above described methods, the consistency of the estimates of each respondent/expert and the judgements of the whole group were determined.

The bar diagrams of calculated average ranks $\bar{R}_{k}$ assigned by all respondents and experts to criterion groups $\mathrm{A}, \mathrm{B}, \mathrm{C}$ and $\mathrm{D}$ (Table 2) describing the quality of the railway trip are presented in Figures 4, 5 and 6. 
Table 5. A questionnaire for ranking criterion groups A, B, C and D describing the quality of a railway trip (including ranks $R_{1}$ )

\begin{tabular}{clc}
\hline $\begin{array}{c}\text { No of the } \\
\text { criteria group }\end{array}$ & \multicolumn{1}{c}{ A group and brief description of criteria } & Rank \\
\hline 1 & Cost of the trip (C) (ticket price, medical care insurance abroad, visa, etc.) & 4 \\
\hline 2 & $\begin{array}{l}\text { Train elements and technical state of rails (A) (roughness of a track, } \\
\text { train speed, structure and equipment for a passenger car ensuring } \\
\text { the comfort of passengers) }\end{array}$ & 3 \\
\hline 3 & $\begin{array}{l}\text { Safe railway trip (D) (availability of fire extinguishing and first medical } \\
\text { care facilities, efficiency of wheelset control, fire alarm and manual braking } \\
\text { systems, possibility of calling doctors and policemen to the train) }\end{array}$ & 1 \\
\hline 4 & $\begin{array}{l}\text { Railway trip planning and technology (B) (timely departure and arrival } \\
\text { of the train, quality of services provided on train, the appearance } \\
\text { of service staff, their personal contact with passengers, knowledge of foreign } \\
\text { languages, etc.) }\end{array}$ & 2 \\
\hline
\end{tabular}

Note: 1. The meaning of numerical ranks: 1 (most important); 2 (more important); 3 (important); 4 (of medium importance)

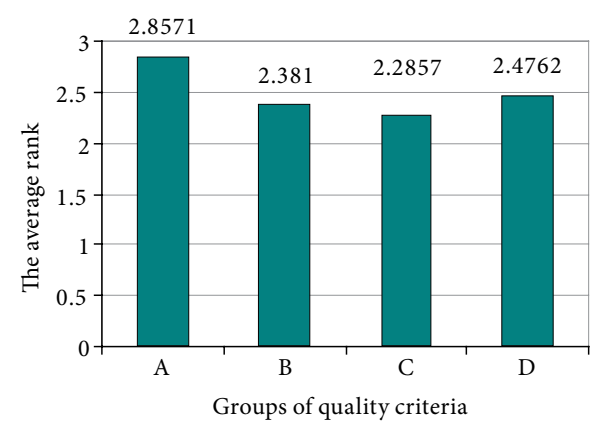

Fig. 4. The bar diagram of average ranks given to criterion groups $\mathrm{A}, \mathrm{B}, \mathrm{C}$ and $\mathrm{D}$ describing the quality of a railway trip considering passengers' position $(n=21), \mathrm{W}=0.038, W_{\min }=0.180$, $\chi^{2}=2.37, \quad \chi_{\alpha, v}^{2}=11.34$

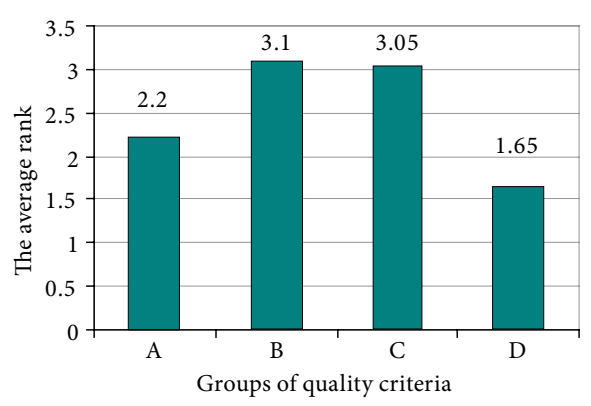

Fig. 5. The bar diagram of average ranks given to criterion groups $\mathrm{A}, \mathrm{B}, \mathrm{C}$ and $\mathrm{D}$ describing the quality of a railway trip considering the position of the service staff of the train $(n=20), \mathrm{W}=0.295$, $W_{\min }=0.189, \chi^{2}=17.70, \chi_{\alpha, v}^{2}=11.34$

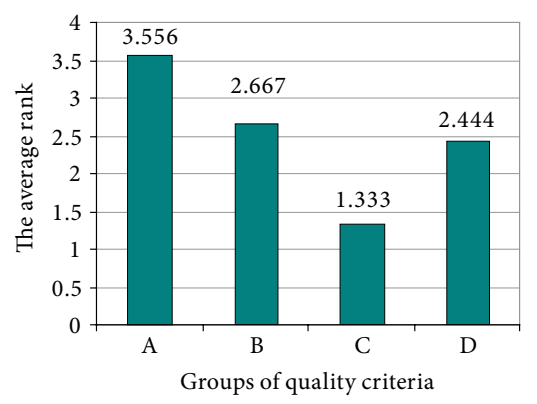

Fig. 6. The bar diagram of average ranks given to criterion groups A, B, C and D describing the quality of a railway trip considering the position of the administrative staff of the company Lietuvos geležinkeliai $(n=9), \mathrm{W}=0.501, W_{\min }=0.420, \chi^{2}=13.53, \chi_{\alpha, v}^{2}=11.34$ 


\section{Comparative analysis of the significance of criterion groups A, B, C and D describing the quality of the railway trip and opinions of the respondents and experts involved into the evaluation process}

Table 6 provides general data on questionnaires, including estimates $R_{j}$ showing the significance of criterion groups A, B, C and D describing the quality of a railway trip, interpreted by the surveyed respondents ( 21 passengers) and experts ( 20 members of the train team and 9 staff members of the company Lietuvos geležinkeliai). Based on the methods described above, the consistency of opinions expressed by the respondents and experts representing two different categories as well as the consistency of the estimates elicited from all respondents and experts (50 evaluators) (Table 6) was determined.

The significance indicator $Z_{j}$ of any criterion obtained from the respondents and experts is calculated using formula (8).

The calculated average ranks $\bar{R}_{k}$ given to criterion groups $\mathrm{A}, \mathrm{B}, \mathrm{C}$ and $\mathrm{D}$ describing the quality of a railway trip show that criterion $C$ is more significant than $B, D$ and $A$, i.e. the following hierarchical order is obtained: $\mathrm{C}>\mathrm{B}>\mathrm{D}>\mathrm{A}$. However, from the point of view of the service staff of the train, average ranks $\bar{R}_{k}$ given by them to criterion groups A, B, C and $\mathrm{D}$ describing the quality of a railway trip indicate that criterion $\mathrm{D}$ is more important than criteria A, C and B implying that the hierarchical order is as follows: $\mathrm{D}>\mathrm{A}>\mathrm{C}>\mathrm{B}$. From the point of view of the administrative staff of Lietuvos geležinkeliai - $\mathrm{C}>\mathrm{D}>\mathrm{B}>\mathrm{A}$. The calculated average ranks $\bar{R}_{k}$ do not show the importance of one or another criterion group. The estimates of the respondents (passengers) and experts (administration staff) are closer to each other (Table 7) and match with determining the priority of criterion groups $\mathrm{A}$ and $\mathrm{C}$ with respect to the quality of the railway trip.

Concordance coefficient $W$, critical value $\chi_{\alpha, v}^{2}$ (taken from the distribution table with a respective degree of freedom $\alpha=0.010$ ) and the lowest value of concordance coefficient $W_{\text {min }}$ obtained for the estimates provided by the respondents and experts are given in Table 6 .

The estimates of the significance (preference) of criterion groups A, B, C and D describing the quality of a railway trip are elicited from the respondents (passengers) and remain inconsistent, whereas the judgements made by the experts (train service and administrative staff of the company Lietuvos geležinkeliai) are consistent. A general opinion of all respondents and experts also lacks consistency. It can be assumed that the interests and requirements of

Table 6. Concordance coefficient $W$, critical value $\chi_{\alpha, v}^{2}$ and the lowest concordance coefficient $W_{\text {min }}$ obtained for the estimates provided by the experts $(\mathrm{P}, \mathrm{A})$ and respondents $(\mathrm{K})$

\begin{tabular}{ccccc}
\hline \multirow{2}{*}{$\begin{array}{c}\text { The category of } \\
\text { respondents and experts }\end{array}$} & \multicolumn{4}{c}{ Value } \\
\cline { 2 - 5 } & $W$ & $W_{\text {min }}$ & $\chi^{2}$ & $\chi_{\alpha, \nu}^{2}$ \\
\hline $\mathrm{K}$ & 0.038 & 0.180 & 2.37 & 11.34 \\
\hline $\mathrm{P}$ & 0.295 & 0.189 & 17.70 & 11.34 \\
\hline $\mathrm{A}$ & 0.501 & 0.420 & 13.53 & 11.34 \\
\hline $\mathrm{B}(\mathrm{K}, \mathrm{P}, \mathrm{A})$ & 0.047 & 0.0756 & 6.984 & 11.34 \\
\hline
\end{tabular}

*The categories of respondents and experts: $\mathrm{K}$ - passengers, $\mathrm{P}$ - service staff of the train, $\mathrm{A}$ - administrative staff, $\mathrm{B}$ - both respondents (passengers) and experts (train service and administrative staff) 
Table 7. The number of tied ranks obtained from the respondents and experts

\begin{tabular}{cccc}
\hline Group of criteria & $\mathrm{K}=\mathrm{P}$ & $\mathrm{K}=\mathrm{A}$ & $\mathrm{P}=\mathrm{A}$ \\
\hline $\mathrm{A}$ & 0 & 1 & 0 \\
\hline $\mathrm{B}$ & 0 & 0 & 0 \\
\hline $\mathrm{C}$ & 0 & 1 & 0 \\
\hline $\mathrm{D}$ & 0 & 0 & 0 \\
\hline Total & 0 & 2 & 0 \\
\hline
\end{tabular}

${ }^{*}$ The notation of respondent and expert categories: $\mathrm{K}$ - passengers, $\mathrm{P}$ - service staff of the train, $\mathrm{A}$ - administrative staff

passengers differ to great extent: for example, some of them are primarily interested in low ticket prices actually ignoring the level of comfort, while others, on the contrary, give preference to comfort not paying much attention to the ticket price.

The estimates of the significance of criterion group A determined by the respondents and experts of all three categories (K, P, A) take part in the survey, are expressed by the mean value of weight coefficient $\bar{Z}_{A}$ (when the number of the respondents and experts in each category is the same) and are calculated applying the formula

$$
\bar{Z}_{A}=\frac{\sum_{e=1}^{3} Z_{A e}}{3}=\frac{Z_{A K}+Z_{A P}+Z_{A A}}{3},
$$

where $Z_{A}$ is weight coefficient given by the respondents of the e-th category (experts) to criterion group A; $Z_{A K}$ is weight assigned to criterion group A by passengers; $Z_{A P}$ is weight assigned to criterion group $\mathrm{A}$ by the service staff of the train; $Z_{A A}$ is weight assigned to criterion group A by administrative staff.

The mean values of weight coefficients $\bar{Z}_{B}, \bar{Z}_{C}, \bar{Z}_{D}$ of other criterion groups (B, C, D) were calculated employing similar formulas (Table 8):

$$
\begin{aligned}
& \bar{Z}_{B}=\frac{\sum_{e=1}^{3} Z_{B e}}{3}=\frac{Z_{B K}+Z_{B P}+Z_{B A}}{3} ; \\
& \bar{Z}_{C}=\frac{\sum_{e=1}^{3} Z_{C e}}{3}=\frac{Z_{C K}+Z_{C P}+Z_{C A}}{3} ; \\
& \bar{Z}_{D}=\frac{\sum_{e=1}^{3} Z_{D e}}{3}=\frac{Z_{D K}+Z_{D P}+Z_{D A}}{3} .
\end{aligned}
$$

The significance of criterion group A determined by the respondents and experts of all three categories $\left(\mathrm{K}, \mathrm{P}, \mathrm{A}\right.$ ) is expressed by the mean value of weight coefficient $\bar{Z}_{A}^{*}$ (when the number of the respondents and experts in each category is not the same). This coefficient is calculated by the formula 


$$
\bar{Z}_{A}^{*}=\frac{\sum_{i=1}^{n} Z_{i} \cdot n_{e}}{\sum_{e=1}^{N} n_{e}}=\frac{Z_{A K} \cdot n_{K}+Z_{A P} \cdot n_{P}+Z_{A A} \cdot n_{A}}{n_{K}+n_{P}+n_{A}},
$$

where $Z_{A K}, Z_{A P}, Z_{A A}$ denote weight coefficient given by the respondents (experts) of categories $\mathrm{K}, \mathrm{P}$ and $\mathrm{A}$ to criterion group $\mathrm{A} ; n_{K}, n_{P}, n_{A}$ are the numbers of the respondents $(\mathrm{K})$ and experts (P, A).

In the considered case, the number of the respondents and experts is not the same, and therefore formula (17) is used, which is more suitable because the respondents make a larger part - 21 passengers. The performed research accepts the opinion of passengers to be of primary importance.

Mean weight coefficient $\bar{Z}_{k}^{*}$ showing the significance of criterion groups B, C and D was determined by the respondents and experts of categories $\mathrm{K}, \mathrm{P}$ and $\mathrm{A}$, and therefore is calculated applying formulas:

$$
\begin{aligned}
& \bar{Z}_{B}^{*}=\frac{\sum_{i=1}^{n} Z_{i} \cdot n_{e}}{\sum_{e=1}^{N} n_{e}}=\frac{Z_{B K} \cdot n_{K}+Z_{B P} \cdot n_{P}+Z_{B A} \cdot n_{A}}{n_{K}+n_{P}+n_{A}} ; \\
& \bar{Z}_{C}^{*}=\frac{\sum_{i=1}^{n} Z_{i} \cdot n_{e}}{\sum_{e=1}^{N} n_{e}}=\frac{Z_{C K} \cdot n_{K}+Z_{C P} \cdot n_{P}+Z_{C A} \cdot n_{A}}{n_{K}+n_{P}+n_{A}} ; \\
& \bar{Z}_{D}^{*}=\frac{\sum_{i=1}^{n} Z_{i} \cdot n_{e}}{\sum_{e=1}^{N} n_{e}}=\frac{Z_{D K} \cdot n_{K}+Z_{D P} \cdot n_{P}+Z_{D A} \cdot n_{A}}{n_{K}+n_{P}+n_{A}} .
\end{aligned}
$$

A general model for calculating the quality of a passenger train, when the weight coefficients of criterion groups were obtained by expert evaluation, is determined by the formula:

$$
\begin{aligned}
& K=\sum_{k=1}^{4}\left[\bar{Z}_{k}^{*} \cdot\left(\sum_{j=1}^{m} \bar{Q}_{k j} \cdot x_{k j}\right)\right]= \\
& \bar{Z}_{A}^{*} \cdot\left(\sum_{j=1}^{16} \bar{Q}_{A j} \cdot x_{A j}\right)+\bar{Z}_{B}^{*} \cdot\left(\sum_{j=1}^{19} \bar{Q}_{B j} \cdot x_{B j}\right)+ \\
& \bar{Z}_{C}^{*} \cdot\left(\sum_{j=1}^{6} \bar{Q}_{C j} \cdot x_{C j}\right)+\bar{Z}_{D}^{*} \cdot\left(\sum_{j=1}^{8} \bar{Q}_{D j} \cdot x_{D j}\right),
\end{aligned}
$$

where $K$ is the complex quality evaluation criterion of an international train ( $K$ may be in the range from 0 to 1 ); $\bar{Q}_{A j}, \bar{Q}_{B j}, \bar{Q}_{C j}, \bar{Q}_{D j}$ denote the mean weights of the $j$-th criteria 
562 L. Maskeliūnaitè, H. Sivilevičius. Expert evaluation of criteria describing the quality of travelling...

of the $k$-th group determined by the expert evaluation method; $x_{A j}, x_{B j}, x_{C j}, x_{D j}$ are the variables of the $j$-th criteria of the $k$-th group used for calculating the real criterion value ranging from 0 to 1 .

The calculation results of significance (weight) $Z_{k}$ and the ranks of criterion groups A, $\mathrm{B}, \mathrm{C}$ and $\mathrm{D}$ describing the quality of the railroad trip determined by passengers $(\mathrm{K})$, service staff of the train (P) and administrative staff (A) of the company Lietuvos geležinkeliai are given in Table 8 . The broken lines of significance (weight) $Z_{k}$ and mean weight coefficients $\bar{Z}_{k}, \bar{Z}_{k}^{*}$ are shown in Fig. 7 .

Passengers think that criterion group $\mathrm{C}$ describing the quality of the trip by international train is the most important because $\mathrm{Z}_{C K}=0.2714$. Criterion group $\mathrm{B}$ seems to be less important because $\mathrm{Z}_{B K}=0.2619$ while criterion group $\mathrm{A}$ with $\mathrm{Z}_{A K}=0.2143$ is assessed as the least important (Fig. 7). For the service staff of the train, criterion group $A\left(Z_{A P}=0.2800\right)$ followed by criterion group $\mathrm{D}\left(\mathrm{Z}_{D P}=0.3350\right)$ is the most significant. The administrative staff of Lietuvos geležinkeliai believe that criterion group $\mathrm{C}$ with respective $\mathrm{Z}_{C A}=0.3667$ is definitely the most important while criterion group $A$ is the least important due to the fact that, in this case, $\mathrm{Z}_{A A}=0.1444$. The values of weight coefficients often differ or even contradict each other. The mean values of the weight coefficients of various groups of criteria are calculated using different formulas. Therefore, they show that criterion group $\mathrm{D}$ is more significant than group $\mathrm{C}$, while $\mathrm{C}$ is more important than $\mathrm{B}$ and $\mathrm{B}$, in turn, is more important than A. The considered data allow for a conclusion that railway and train parameters (criterion group A) are the least important for all categories of the respondents and experts, whereas the parameters of traffic safety (criterion group D), on the contrary, are the most important.

Table 8. Significance (weight) and preference order (rank) of criterion groups A, B, C and D describing the quality of the railroad trip determined by passengers $(\mathrm{K})$, service staff of the train $(\mathrm{P})$ and administrative staff (A) of the company Lietuvos geležinkeliai

\begin{tabular}{lcccccc}
\hline & Weights & \multicolumn{5}{c}{$\begin{array}{c}\text { Criterion group describing the quality } \\
\text { of the railway trip }\end{array}$} \\
\cline { 2 - 7 } & $Z_{k}, \bar{Z}_{k}, \bar{Z}_{k}^{*}$ & $\mathrm{~A}$ & $\mathrm{~B}$ & $\mathrm{C}$ & $\mathrm{D}$ & Total \\
\hline Passengers $(n=21)$ & & & & & \\
\hline$Z_{k K}$ & 0.2143 & 0.2619 & 0.2714 & 0.2524 & 1.000 \\
\hline Rank (preference order) & 4 & 2 & 1 & 3 & - \\
\hline Service staff of the train $(n=20)$ & & & & & \\
\hline$Z_{k P}$ & 0.2800 & 0.1900 & 0.1950 & 0.3350 & 1.000 \\
\hline Rank & 2 & 4 & 3 & 1 & - \\
\hline Administrative staff of Lietuvos geležinkeliai $(n=9)$ & & & & & \\
\hline$Z_{k A}$ & 0.1444 & 0.2333 & 0.3667 & 0.2556 & 1.000 \\
\hline Rank & 4 & 3 & 1 & 2 & - \\
\hline $\begin{array}{l}\text { The average estimate of all experts and respondents } \\
(n=50) \bar{Z}_{k}\end{array}$ & 0.2129 & 0.2284 & 0.2777 & 0.2810 & 1.000 \\
\hline $\begin{array}{l}\text { The average estimate of all expertsand respondents } \\
\text { taking into account their number in a category } \bar{Z}_{k}^{*}\end{array}$ & 0.2280 & 0.2280 & 0.2580 & 0.2860 & 1.000 \\
\hline
\end{tabular}




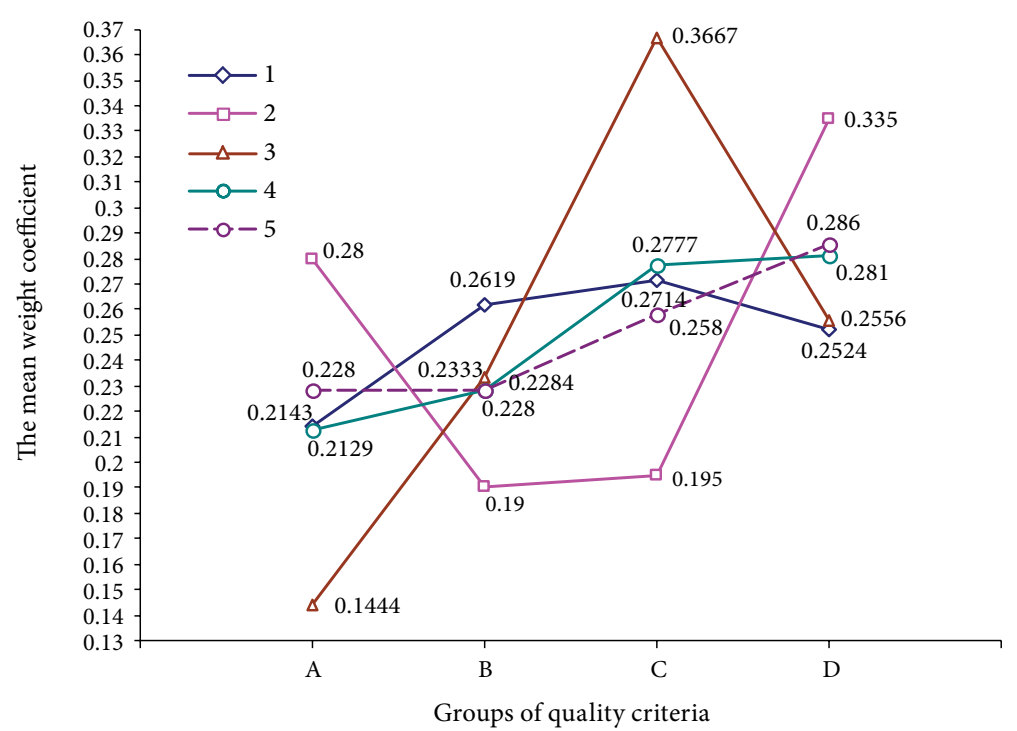

Fig. 7. Broken lines showing the weight of a quality railway trip taking into account criterion groups $A, B, C$ and $D$ given by 1 ) passengers $(K) ; 2)$ service staff of the train $(\mathrm{P}) ; 3)$ administrative staff of Lietuvos geležinkeliai $(\mathrm{A}) ; 4)$ all experts and residents $(n=50)$ based on their mean estimate $\bar{Z}_{k}$; 5) all experts and residents $(n=50)$ based on mean estimate $\bar{Z}_{k}^{*}$ of all experts and residents taking into account the number in a category

\section{Conclusions}

The processed data obtained from the surveyed respondents (passengers) and experts (service staff of the train and administrative staff of the joint-stock company Lietuvos geležinkeliai) show that the problem of the quality of the railway trip allow the authors determining the weight (significance) of criterion groups A, B, C and D and individual criteria describing the quality of the railway trip in various trains and expressing it in a single number.

The use of methods for expert evaluation and AHP technique in particular was a difficult task of the conducted research. Differently from the respondents, the passengers of the train did not show enough initiative. The motivation and experience of the service staff of the train helped them with filling in the questionnaires. The passengers' $(K)$ estimates of the significance of criterion groups A, B, C and D describing the quality of the railway trip are not consistent. The needs of passengers vary to great extent: some are interested in the trip cost ignoring the range and quality of the provided services while the other part requires various high-quality services and comfort at any cost.

The opinions of service staff $(\mathrm{P})$ on criterion groups $\mathrm{A}, \mathrm{B}, \mathrm{C}$ and $\mathrm{D}$ describing the quality of the railway trip are in a good agreement (consistent). These people are qualified evaluators.

The estimates of the administrative staff of Lietuvos geležinkeliai provided for criterion groups A, B, C and D describing the quality of the railway trip are consistent. 
564 L. Maskeliūnaitè, H. Sivilevičius. Expert evaluation of criteria describing the quality of travelling ...

The opinions of passengers and administrative staff about the significance (preference) of criterion groups $\mathrm{A}, \mathrm{B}, \mathrm{C}$ and $\mathrm{D}$ describing the quality of the railway trip are similar.

The present investigation has determined the weight coefficients $\bar{Z}_{k}^{*}$ of the groups of criteria of the additive model (20) and the mean weight coefficients $\bar{Q}_{k j}$ of the particular criteria of these groups.

\section{Acknowledgements}

The authors express their gratitude to the administration of the joint-stock company Lietuvos geležinkeliai for the provided possibility of conducting a survey in the train 'Vilnius-Moscow'. They also thank administration, train service staff and passengers for participating in research.

\section{References}

Brauers, W. K. M.; Zavadskas, E. K.; Peldschus, F.; Turskis, Z. 2008. Multi-objective decision-making for road design, Transport 23(3): 183-193. http://dx.doi.org/10.3846/1648-4142.2008.23.183-193

Belov, I. V.; Tereshina, N. P.; Galaburda, V. G., et al. 2001. Ekonomika zheleznodorozhnogo transporta. Moskva: Marshrut. 600 s. ISBN 5-89035-056-0.

Bureika, G. 2011. Multicriteria evaluation of operational effectiveness of freight diesel locomotives on Lithuanian railways, Transport 26(1): 61-68. http://dx.doi.org/10.3846/16484142.2011.561947

Campbell, J. M.; Smith, S. D.; Forde, M. Ch.; Ladd, R. D. 2007. Identifying hazards in transportation construction and maintenance tasks. Case-based reasoning approach using railroad data, Transportation Research Record 1995: 69-75. http://dx.doi.org/10.3141/1995-09

Clever, R.; Hansen, M. M. 2008. Interaction of air and high-speed rail in Japan, Transportation Research Record 2043: 1-12. http://dx.doi.org/10.3141/2043-01

Dailydka, S. 2010. Choosing railway vehicles for carrying passengers, Transport 25(1): 11-16. http://dx.doi.org/10.3846/transport.2010.02

Dinh, V. N.; Kim, K. D.; Warnitchai, P. 2009. Dynamic analysis of three-dimensional bridge-high-speed train interactions using a wheel-rail contact model, Engineering Structures 31: 3090-3106. http://dx.doi.org/10.1016/j.engstruct.2009.08.015

Fitzmaurice, M. 2005. Use of wireless local area networks in rail and urban transit environments, Transportation Research Record 1916: 42-46. http://dx.doi.org/10.3141/1916-07

Gašparík, J.; Zitrický, V. 2010. A new approach to estimating the occupation time of the railway infrastructure, Transport 25(4): 387-393. http://dx.doi.org/10.3846/transport.2010.48

Gelumbickas, G.; Vaičiūnas, G. 2011. Analysis of passenger rolling stock foults and its statistics in Lithuania, Transport 26(3): 315-319. http://dx.doi.org/10.3846/16484142.2011.618190

Hagiwara, Y.; Ishikawa, S.; Furuya, M. 2007. Innovative lightweight technologies using power electronics on shinkansen high-speed electric multiple units, Transportation Research Record 1995: 43-51. http://dx.doi.org/10.3141/1995-06

He, X.-H.; Scanlon, A.; Li, P. 2011. Dynamic factor of bridges subjected to linear induction motor train load, The Baltic Journal of Road and Bridge Engineering 6(3): 185-192. http://dx.doi.org/10.3846/bjrbe.2011.24

Jabri, S.; El Koursi, E. M.; Bourdeaud'huy, T.; Lemaire, E. 2010. European railway traffic management system validation using UML/Petri nets modelling, European Transport Research Review 2(2): 113-128. http://dx.doi.org/10.1007/s12544-010-0030-5 
Kendall, M. E. 1970. Rank Correlation Methods. $4^{\text {th }}$ ed. London: Griffin and Co.

Kuo, A.; Miller-Hooks, E.; Zhang, K.; Mahmassani, H. 2008. Train slot cooperation in multicarrier, international rail-based intermodal freight transport, Transportation Research Record 2043: 31-40. http://dx.doi.org/10.3141/2043-04

Lei, X.; Zhang, B. 2011. Analysis of dynamic behavior for slab track of high-speed railway based on vehicle and track elements, Journal of Transportation Engineering 137(4): 227-240. http://dx.doi.org/10.1061/(ASCE)TE.1943-5436.0000207

Li, D.; Bilow, D. N. 2008. Testing of slab track under heavy axle loads, Transportation Research Record 2043: 55-64. http://dx.doi.org/10.3141/2043-07

Martinelli, F.; Cara, S.; Domenichini, L. 2008. Rail tunnel risk analysis. A tool to improve rail tunnel design, Transportation Research Record 2043: 41-48. http://dx.doi.org/10.3141/2043-05

Maskeliūnaité, L.; Sivilevičius, H.; Podvezko, V. 2009. Research on the quality of passenger transportation by railway, Transport 24(2): 100-112. http://dx.doi.org/10.3846/1648-4142.2009.24.100-112

Maskeliunaite, L.; Sivilevicius, H. 2011. Applying AHP technique to the assessment of railway trip quality (RTQ), in The $8^{\text {th }}$ International Conference "Environment Engineering": Selected papers, vol. 3. Ed. by Čygas, D.; Froehner, K. D. May 19-20, 2011, Vilnius, Lithuania. Vilnius: Technika, 1133-1141.

Metinè ataskaita [Annual report]. 2010. Joint-Stock Company 'Lithuanian Railways' (AB „Lietuvos geležinkeliai“).

Morgan, C. A.; Olson, L. E.; Kyte, T. B. 2007. Development and pilot testing of crew resource management training program for railroad industry, Transportation Research Record 1995: 62-68. http://dx.doi.org/10.3141/1995-08

Morkvenas, R.; Bivainis, J.; Jaržemskis, A. 2008. Assessment of employee’s knowledge potential in transport sector, Transport 23(3): 258-265. http://dx.doi.org/10.3846/1648-4142.2008.23.258-265

Nakagawa, A.; Matsuda, S. 2005. Status of development and running tests on Japan's superconducting maglev, Transportation Research Record 1916: 26-29. http://dx.doi.org/10.3141/1916-04

Preston, J.; Wal, G.; Batley, R.; Ibáñez, J. N.; Shires, J. 2009. Impact of delays on passenger train services, Transportation Research Record 2117: 14-23. http://dx.doi.org/10.3141/2117-03

Podvezko, V. 2005. Agreement of expert estimates, Technological and Economic Development of Economy 11(2): 101-107.

Ramunas, V.; Gailienè, I.; Podagelis, I. 2011. Increment of railway line capacity, in The $8^{\text {th }}$ International Conference "Environment Engineering": Selected papers, vol. 3. Ed. by Čygas, D.; Froehner, K. D. May 19-20, 2011, Vilnius, Lithuania. Vilnius: Technika, 1193-1199.

Rao, A.; Tsai, T. 2007. Safety standards for high-speed rail transportation, Transportation Research Record 1995: 35-42. http://dx.doi.org/10.3141/1995-05

Saaty, T. L. 1980. The Analytical Hierarchy Process. New York: M. Graw-Hill.

Sasaki, K. 2005. Position-detecting system based on the global positioning system. Potential use in improving car body tilt control, Transportation Research Record 1916: 30-33. http://dx.doi.org/10.3141/1916-05

Scalea, F. L.; Bartoli, I.; Rizzo, P.; Fateh, M. 2005. High-speed defect detection in rails by noncontact guided ultrasonic testing, Transportation Research Record 2005: 66-77. http://dx.doi.org/10.3141/1916-10

Schwieterman, J. P.; Scheidt, J. 2007. Survey of current high-speed rail planning efforts in the United States, Transportation Research Record 1995: 27-34. http://dx.doi.org/10.3141/1995-04

Si, B.; Zhong, M.; Gao, Z. 2009. Bilevel programming for evaluating revenue strategy of railway passenger transport under multimodal market competition, Transportation Research Record 2117: 1-6.

http://dx.doi.org/10.3141/2117-01 
Sivilevičius, H.; Maskeliūnaité, L. 2010. The criteria for identifying the quality of passengers' transportation by railway and their ranking using AHP method, Transport 25(4): 368-381.

http://dx.doi.org/10.3846/transport.2010.46

Sivilevičius, H. 2011a. Modelling the interaction of transport system elements, Transport 26(1): 20-34. http://dx.doi.org/10.3846/16484142.2011.560366

Sivilevičius, H. 2011b. Application of expert evaluation method to determine the importance of operating asphalt mixing plant quality criteria and rank correlation, The Baltic Journal of Road and Bridge Engineering 6(1): 48-58. http://dx.doi.org/10.3846/bjrbe.2011.07

Sivilevičius, H.; Zavadskas, E. K.; Turskis, Z. 2008. Quality attributes and complex assessment methodology of the asphalt mixing plant, The Baltic Journal of Road and Bridge Engineering 3(3): 161-166. http://dx.doi.org/10.3846/1822-427X.2008.3.161-166

Somov, D.; Bazaras, Ž. 2011. The restoration of physical and mechanical properties of wheel rim metal, Transport 26(3): 240-247. http://dx.doi.org/10.3846/16484142.2011.622132

Stribersky, A.; Moser, F.; Rulka, W. 2000. Structural dynamics of rail vehicle systems: a virtual systems approach, Developments in Engineering Computational Technology, 29-36.

Turskis, Z.; Zavadskas, E. K. 2010. A new fuzzy additive ratio assessment method (ARAS-F). Case study: the analysis of fuzzy multiple criteria in order to select the logistic centers location, Transport 25(4): 423-432. http://dx.doi.org/10.3846/transport.2010.52

Vilčeková, S.; Krídlová Burdová, E.; Ondová, M. 2011. Site selection and project planning resulting in sustainable buildings, in The $8^{\text {th }}$ International Conference "Environment Engineering": Selected papers, vol. 3. Ed. by Čygas, D.; Froehner, K. D. May 19-20, 2011, Vilnius, Lithuania. Vilnius: Technika, 1009-1013.

White, T. 2005. Alternatives for railroad traffic simulation analysis, Transportation Research Record 1916: 34-41. http://dx.doi.org/10.3141/1916-06

Zavadskas, E. K. 1987. Kompleksnaia otsenka i vybor resursosberegaiushchikh reshenij v stroitelstve. Vilnius: Mokslas. $212 \mathrm{~s}$.

Zhao, J.; Chan, A. H. C.; Burrow, M. P. N. 2007. Probabilistic model for predicting rail breaks and controlling risk of derailment, Transportation Research Record 1995: 76-83. http://dx.doi.org/10.3141/1995-10

Zhu, Z-y.; Ling, X-z.; Chen, S-j.; Zhang, F.; Wang, Z-y.; Wang, L-n.; Zou, Z-y. 2011. Analysis of dynamic compressive stress induced by passing trains in permafrost subgrade along Qinghai-Tibet Railway, Cold Regions Science and Technology 65: 465-473. http://dx.doi.org/10.1016/j.coldregions.2010.10.011

Lijana MASKELIŪNAITĖ. Doctoral student at the Department of Technological Transport Equipment, Faculty of Transport Engineering, Vilnius Gediminas Technical University. Transport engineer (2006) from the Department of Technological Transport Equipment, Faculty of Transport Engineering, Vilnius Gediminas Technical University. MSc in transport engineering (2008). Co-author of 4 scientific papers. Several years of experience of passenger transportation by railway, including the organization of passenger railway travel, provision of services for passengers and service quality. Research interests: passenger transportation by railway.

Henrikas SIVILEVIČIUS. Dr Habil Prof. at the Department of Transport Technological Equipment, Vilnius Gediminas Technical University, Lithuania. PhD in the construction of automobile roads (1984). $\mathrm{Dr}$ Sc (2002) in civil engineering. The author and co-author of more than 180 research papers. Research interests: hot mix asphalt (HMA) production quality and development of quality control methods; statistical and expert methods used in the transport system, methods for assessing the state and service life of flexible road pavement. 